FUNGSI DAN IMPLEMENTASI

\title{
TARIF PROGRESIF DALAM PAJAK KENDARAAN BERMOTOR” \\ (Kajian Empiris di Provinsi DKI Jakarta).
}

YOHANES PEMANDI ${ }^{1}$

\begin{abstract}
ABSTRAK
Undang-Undang Nomor 32 Tahun 2004 dan Undang-Undang Nomor 33 Tahun 2004 sebagai landasan penyelenggaraan otonomi daerah saat ini. Kegiatan otonomi daerah dibiayai oleh pemasukan dari Anggaran Pendapatan dan Belanja Negara dan dari Pendapatan Asli Daerahnya masing-masing.

Salah satu sumber Pendapatan Asli Daerah adalah pajak daerah dan retribusi daerah. Saat ini, kebijakan penerapan pajak daerah dan retribusi daerah diatur melalui Undang-Undang Nomor 28 Tahun 2009. Dalam Undang-Undang ini terdapat beberapa hal yang baru dalam penerapannya di Indonesia, salah satunya adalah mengenai penerapan tarif progresif pada pajak kendaraan bermotor pribadi.

Peraturan Daerah Provinsi Daerah Khusus Ibukota Jakarta Nomor 8 Tahun 2010 tentang Pajak Kendaraan Bermotor merupakan salah satu aturan pelaksana dari UndangUndang Nomor 28 Tahun 2009. Tarif progresif ini akan memberikan beban tambahan dalam hal biaya kepemilikan kendaraan bermotor pribadi dan Pemerintah Daerah mendapatkan pendapatan yang lebih banyak untuk mengelola dan mengembangkan ruas-ruas jalan raya dan moda transportasi umum di daerahnya.

Penelitian menggunakan metode penelitian campuran, yaitu metode yuridis normatif (kualitatif) dan metode yuridis empiris (kuantitatif). Hasil dari pungutan pajak kendaraan bermotor akan lebih menambah kemampuan Pemerintah Provinsi DKI Jakarta untuk mengelola dan mengembangkan ruas-ruas jalan raya dan moda transportasi umum di daerahnya. Namun, fungsi regulasi yang ingin dicapai melalui Pajak Kendaraan Bermotor, tidak akan pernah mencapai tujuannya. Kendalanya terletak pada faktor internal dan eksternal yang mempengaruhi pola hidup subjek pajak dari pajak kendaraan bermotor di Jakarta.

Pembenahan ke depan diarahkan pada revisi kebijakan yang mengatur tentang penerapan besaran tarif progresif. Pemerintah juga harus mampu membuat kebijakan lain yang dapat mendukung keberhasilan dari penerapan tarif progresif pada pajak kendaraan bermotor ini.
\end{abstract}

Kata Kunci : Fungsi dan Implementasi, Tarif Progresif, Pajak Kendaraan Bermotor, Provinsi Daerah Khusus Ibukota Jakarta

\footnotetext{
${ }^{1}$ Mahasiswa Program Studi Magister Ilmu Hukum Undip
} 


\section{A. PENDAHULUAN 1.}

\section{Latar Belakang}

Provinsi DKI Jakarta dengan posisinya yang strategis sebagai pusat pemerintahan dan pusat perekonomian menjadi daya tarik tersendiri bagi para investor yang akan melakukan investasi di Indonesia. Kemudahan fasilitas, sarana dan prasarana yang memadai, serta tingkat efisiensi operasional yang lebih tinggi, mendukung para investor untuk menanamkan investasinya di Jakarta. Namun, posisi yang strategis ini juga membawa dampak negatif berupa tingkat kepadatan penduduk dan kendaraan bermotor di DKI Jakarta.

Polda Metro Jaya mencatat, pada tahun 2009, jumlah kendaraan yang berdomisili Kota Jakarta saja sudah mencapai angka 6.688 .913 buah (2.355.354 mobil dan 4.333.559 motor) dengan angka pertambahan kepemilikannya sebesar 1.163 kendaraan per hari sedangkan jumlah kendaraan bermotor yang berada dalam wilayah hukum Polda Metro Jaya (JakartaDepok-Tangerang-Bekasi) mencapai 10.494.689 buah (2.976.591 mobil dan 7.518.098 motor) dengan angka pertumbuhan sebesar 2.320 kendaraan per hari. ${ }^{1}$ Pada tahun 2009 tercatat panjang ruas jalan mencapai 7.616.269 meter dan memiliki luas 47.769 .343 meter persegi. ${ }^{2}$ Rata-rata pertumbuhan jumlah kendaraan bermotor antara tahun 2004-2009 mencapai 8,01\% per tahun (untuk yang berdomisili Kota Jakarta) dan $10,44 \%$ per tahun (untuk yang berada di wilayah hukum Polda Metro Jaya). Rata-rata pertumbuhan panjang jalan dalam kurun waktu 2004-2009 hanya 0,01\% per tahun. Dapat dibayangkan bagaimana kondisi jalan di Jakarta pada tahun 2010 ini ketika seluruh unit kendaraan yang beroperasi di Jakarta melakukan aktivitasnya secara bersamasama.

Data diambil dari Laporan Ditlantas Polda Metro Jaya Tahun 2009.

2 Data diambil dari Laporan Dinas Pekerjaan Umum Pemerintah Provinsi DKI Jakarta. 
Tabel 1.1. Data Pertumbuhan Kendaraan Bermotor Di DKI Jakarta.

\begin{tabular}{|c|c|c|c|c|c|c|}
\hline \multirow[b]{2}{*}{ Tahun } & \multicolumn{2}{|c|}{ Jumlah } & \multicolumn{3}{|c|}{ Pertambahan (per hari) } & \multirow[b]{2}{*}{ (\% per tahun) } \\
\hline & Mobil & Motor & Mobil & Motor & Jumlah & \\
\hline 2004 & 2.016 .237 & 2.534 .480 & - & - & - & - \\
\hline 2005 & 2.110 .249 & 2.887 .172 & 258 & 966 & 1.224 & 9,8 \\
\hline 2006 & 2.161 .653 & 3.242 .090 & 141 & 972 & 1.113 & 8,1 \\
\hline 2007 & 2.218 .380 & 3.579 .622 & 155 & 925 & 1.080 & 7,3 \\
\hline 2008 & 2.295 .644 & 3.968 .749 & 212 & 1.066 & 1.278 & 8,0 \\
\hline 2009 & 2.355 .354 & 4.333 .559 & 164 & 999 & 1.163 & 6,8 \\
\hline \multicolumn{3}{|c|}{ Rata-rata Pertambahan Jumlah } & 186 & 986 & 1.172 & 8,01 \\
\hline & & & kend./hari & kend./hari & kend./hari & \\
\hline
\end{tabular}

Tabel 1.2. Data Pertumbuhan Kendaraan Bermotor Di Wilayah Hukum Polda Metro Jaya (Jakarta - Depok - Tangerang - Bekasi).

\begin{tabular}{|c|c|c|c|c|c|c|}
\hline \multirow[b]{2}{*}{ Tahun } & \multicolumn{2}{|c|}{ Jumlah } & \multicolumn{3}{|c|}{ Pertambahan (per hari) } & \multirow[b]{2}{*}{ (\% per tahun) } \\
\hline & Mobil & Motor & Mobil & Motor & Jumlah & \\
\hline 2004 & 2.450 .219 & 3.940 .700 & - & - & - & - \\
\hline 2005 & 2.582 .884 & 4.647 .435 & 363 & 1.936 & 2.300 & 13,1 \\
\hline 2006 & 2.657 .430 & 5.310 .068 & 204 & 1.815 & 2.020 & 10,2 \\
\hline 2007 & 2.753 .792 & 5.974 .173 & 264 & 1.819 & 2.083 & 9,5 \\
\hline 2008 & 2.882 .202 & 6.765 .723 & 352 & 2.169 & 2.520 & 10,5 \\
\hline 2009 & 2.976 .591 & 7.518 .098 & 259 & 2.061 & 2.320 & 8,8 \\
\hline \multicolumn{3}{|c|}{ Rata-rata Pertambahan Jumlah } & 288 & 1.960 & 2.249 & 10,44 \\
\hline & & & kend./hari & kend./hari & kend./hari & \\
\hline
\end{tabular}

Diperkirakan apabila tingkat pertambahan jumlah kendaraan bermotor masih sama terjadi pada semester II tahun 2011, luas jalan yang tersedia di Jakarta sudah tidak mampu menampung semua jumlah kendaraan yang berplat B apabila digunakan dalam kurun waktu yang sama di dalam Kota Jakarta. Polda Metro Jaya pun memprediksi, bilamana fenomena ini tidak dicegah, pada tahun 2014 Jakarta akan mengalami macet total. Kenyataan ini didukung dengan tidak baiknya penerapan kebijakan mengenai pengadaan alat transportasi umum di Jakarta. Pada akhirnya, kemacetan dan kepulan asap penuh timbal dari gas buang kendaraan bermotor yang beroperasi yang akan memenuhi udara bebas di Jakarta, terutama pada saat jam sibuk (peak time). 
Kondisi udara di Indonesia, terutama di DKI Jakarta, memang sudah dalam tahap yang mengkhawatirkan dan diperlukan adanya tindakan yang harus segera dilakukan guna mengatasi segala permasalahan yang terjadi. Hal tersebut dikarenakan adanya penggunaan kendaraan bermotor dalam jumlah yang melebihi batas maksimalnya. Asap kendaraan bermotor menjadi urutan pertama dan tercatat angka $75 \%$ sebagai penyumbang polusi udara di Indonesia. ${ }^{3}$ Menurut Budi Haryanto, seorang peneliti di Pusat Penelitian Kesehatan Universitas Indonesia, mengatakan bahwa Indonesia menjadi satusatunya negara di Asia Tenggara yang belum bebas timbal dan Indonesia menduduki peringkat ketiga dunia dalam hal tingkat polusi udaranya.

Pada tahun 2004, Uni Eropa menetapkan standar baku mutu tingkat polusi partikel debu di udara yang sehat adalah tidak boleh melebihi angka 50 mikrogram per meter kubik. Pada tahun 2004, Bank Dunia mencatat angka polusi partikel debu di udara Jakarta sebesar 104 mikrogram per meter kubik. Deputi Bidang Tata Ruang dan Lingkungan Hidup Pemerintah Provinsi DKI Jakarta, Ahmad Haryadi mengatakan bahwa Jakarta saat ini menjadi kota besar dengan tingkat polusi udara terburuk ketiga di dunia setelah Meksiko dan Thailand. ${ }^{4}$ Kadar emisi kendaraan dan jumlah kendaraan yang beredar merupakan pemicu meningkatnya kadar timbal $(\mathrm{Pb})$ di udara. Timbal-timbal yang berterbangan di udara bebas ini sangat membahayakan kesehatan masyarakat yang berada di lingkungan tersebut. Polutan tersebut dapat merusak kesehatan melalui udara yang dihirup, makanan dan minuman yang masuk ke dalam tubuh, dan melalui kulit manusia yang bersentuhan dengan udara yang telah menyatu dengan polutan tersebut.

Pemerintah Daerah Provinsi DKI Jakarta sudah membuat kebijakankebijakan di bidang kendaraan bermotor, walaupun tidak efektif

3 Data diambil dari laporan Walhi tahun 2009 dalam sub bidang laporan kondisi pencemaran udara di Indonesia.

4 www.mediaindonesia.com/read/2009/10/12/99762/89/14/Polusi-Udara-Jakarta-TerburukKetiga-di-Dunia 
mengatasi masalah kemacetan. Pada era kepemimpinan Sutiyoso di tahun 2004, Pemerintah Provinsi Jakarta mulai menerapkan kebijakan three in one di beberapa ruas jalan guna mengatasi kemacetan lalu-lintas di ruas-ruas tersebut selama 6 (enam) jam dibagi ke dalam 2 (dua) sesi. Kebijakan ini berlaku setiap hari Senin sampai dengan Jumat pada pukul 07.00-10.00 WIB dan pada pukul 16.00-19.00 WIB. ${ }^{5}$ Hal tersebut merupakan salah satu poin dari beberapa poin yang tercantum dalam Keputusan Gubernur Provinsi Daerah Khusus Ibukota Jakarta Nomor 4104/2003 tanggal 23 Desember 2003 tentang Penetapan Kawasan Pengendalian Lalu-Lintas. Menurut Kepala Bidang Teknologi Prasarana Transportasi Prasetyo Atmojo, pembatasan lalu-lintas melalui three in one perlu dilakukan sebagai sarana untuk mendukung kebijakan pengadaan busway (bus trans Jakarta). ${ }^{6}$ Dengan adanya pembatasan ini, menurut Prasetyo Atmojo, masyarakat diharapkan beralih dari kendaraan pribadi kepada kendaraan massal umum guna menekan angka timbal yang dilepas ke udara bebas dari hasil gas buang kendaraan bermotor. Namun, berdasarkan pantauan penulis sampai dengan tahun 2010, kebijakan three in one ini tidak menyelesaikan masalah pengurangan volume penggunaan kendaraan pribadi.

Pemerintah Pusat pun berkomitmen untuk mengeluarkan kebijakankebijakan yang dapat mengatasi masalah kemacetan. Saat ini pajak digunakan sebagai salah satu instrumen oleh Pemerintah untuk mengatasi masalah kemacetan tersebut. Hukum sesuai sifatnya dapat digunakan sebagai suatu alat kontrol sosial dan sebagai alat untuk mengubah perilaku masyarakat yang telah terbentuk sebelumnya. ${ }^{7}$ Pemerintah kemudian menerapkan sistem pajak progresif pada Pajak Kendaraan Bermotor di sektor kendaraan bermotor pribadi. Oleh karena itu,

5 www.surgaku.com/news/ketahui-kawasan-3-in-one-ibu-kota-jakarta.html Saat ini, di beberapa ruas jalan tertentu, three in one sore dimulai pukul 16.30 WIB.

www.tempointeraktif.com/hg/jakarta//2004/01/07/brk,20040107-44,id.html

Esmi Warassih, Pranata Hukum Sebuah Telaah Sosiologis, Semarang: PT Suryandaru Utama, 2005, halaman 133. 
Pemerintah mengharapkan dengan adanya kebijakan tarif pajak progresif kendaraan bermotor pribadi ini, perilaku konsumerisme masyarakat Indonesia di bidang otomotif dapat ditekan sehingga tujuan untuk membatasi jumlah kendaraan bermotor yang beredar di Indonesia (khususnya di tempat yang padat) dapat tercapai dengan baik.

Pemerintah dihadapkan pada permasalahan yang timbul dari sektor perhubungan darat, terutama yang berhubungan dengan kendaraan bermotor pribadi. Pajak progresif merupakan salah satu upaya yang diambil untuk mengatasi masalah tersebut. Wacana penerapan pajak progresif pada pajak kendaraan bermotor pun mulai direalisasikan dengan dikeluarkannya UndangUndang Nomor 28 Tahun 2009 tentang Pajak Daerah dan Retribusi Daerah. Pengaturan tarif pajak progresif tersebut tercantum dalam Pasal 6 ayat 1 huruf b Undang-Undang Nomor 28 Tahun 2009. ${ }^{8}$ Dengan adanya UU ini diharapkan agar Pemerintah Daerah segera merealisasikan kebijakan nasional ini ke dalam kebijakan daerah hingga ke dalam peraturan teknisnya.

Pajak daerah dan retribusi daerah merupakan salah satu sumber pendapatan daerah yang penting guna membiayai penyelenggaraan pemerintahan daerah. Undang-Undang Nomor 28 Tahun 2009, dalam konsiderannya juga memberikan kewenangan tiap-tiap daerah melakukan kebebasan dalam penetapan tarif pajak dengan memperhatikan potensi daerahnya dan tidak bertentangan dengan peraturan perundang-undangan yang berlaku. Undang-Undang Pajak Daerah dan Retribusi Daerah ini membutuhkan peraturan pelaksana berupa Peraturan Daerah agar dapat berlaku secara efektif di masyarakat daerahnya masing-masing.

Kebijakan publik di bidang pajak yang tertuang melalui peraturanperaturan sedapat mungkin diimplementasikan secara maksimal untuk

8 Bilamana diinterpretasikan secara bebas, Pasal 6 ayat 1 huruf b Undang-Undang Nomor 28 menyatakan bahwa untuk kepemilikan kendaraan bermotor kedua dan seterusnya, kendaraan bermotor yang dimaksud dapat dikenakan pajak progresif antara $2 \%$ (dua persen) hingga 10\% (sepuluh persen) lebih tinggi daripada besaran pajak yang sebenarnya (pada kepemilikan kendaraan yang pertama akan dikenakan antara $1 \%$ (satu persen) sampai dengan $2 \%$ (dua persen) dari nilai jual objek pajak). 
mengadakan sarana dan prasarana umum yang langsung dapat dirasakan manfaatnya oleh masyarakat sebagai wajib pajaknya. Hal tersebut ditujukan untuk menghindari adanya keresahan masyarakat dalam menjalankan kewajiban membayar pajaknya di masa krisis ini dan untuk menghindari adanya distorsi terhadap perekonomian, khususnya menimbulkan kelesuan daya beli masyarakat Jakarta.

"Pungutan pajak mengurangi penghasilan/kekayaan individu tetapi sebaliknya merupakan penghasilan masyarakat yang kemudian dikembalikan lagi kepada masyarakat, melalui pengeluaran rutin dan pembangunan yang akhirnya kembali lagi kepada seluruh masyarakat yang bermanfaat bagi rakyat (tidak hanya yang membayar pajak, tetapi juga kepada masyarakat yang tidak membayar pajak)",9

Terdapat hal-hal yang menarik dalam Undang-Undang Nomor 28

Tahun 2009 ini khususnya yang berkaitan dengan Pajak Kendaraan

Bermotor. Hal-hal yang dimaksud adalah sebagai berikut:

1. berdasarkan Pasal 5 ayat 9 Undang-Undang Nomor 28 Tahun 2009, dasar pengenaan Pajak Kendaraan Bermotor dinyatakan dengan penetapan Peraturan Menteri Dalam Negeri setelah mendapat pertimbangan dari Menteri Keuangan sedangkan berdasarkan Pasal 6 ayat 5 Undang-Undang Nomor 28 Tahun 2009, penentuan tarif pajak kendaraan bermotornya ditetapkan dengan Peraturan Daerah;

2. tarif pajak progresif untuk pertama kalinya digunakan dalam menghitung besaran tarif Pajak Kendaraan Bermotor khusus bagi kepemilikan kendaraan bermotor pribadi;

3. Peraturan Daerah tentang Pajak tidak boleh berlaku surut; dan

4. kesemua hal tersebut bertujuan untuk menciptakan asas keadilan di sektor perpajakan kendaraan bermotor dan untuk meningkatkan pelayanan kepada masyarakat dengan memperhatikan prinsip demokrasi, pemerataan dan keadilan, peran serta masyarakat, dan potensi daerahnya masingmasing.

9 Rochmat Soemitro, Pengantar Singkat Hukum Pajak, Bandung: P.T. Eresco, 1992. 
Berdasarkan uraian sebelumnya, maka menarik untuk dikaji kemudian mengenai fungsi pajak dan implementasi dari ketetapan Undang-Undang Nomor 28 Tahun 2009 tentang Pajak Daerah dan Retribusi Daerah yang salah satunya mengatur Pajak Kendaraan Bermotor dan di dalamnya menggunakan tarif progresif untuk pertama kalinya bagi pajak kendaraan bermotor pribadi. Oleh karena itu, penelitian ini akan diberi judul: "FUNGSI DAN IMPLEMENTASI

\section{TARIF PROGRESIF DALAM PAJAK KENDARAAN BERMOTOR”}

(Kajian Empiris di Provinsi DKI Jakarta).

\section{Permasalahan}

Berdasarkan latar belakang dan identifikasi masalah tersebut di atas, akan diangkat tiga permasalahan yang akan diteliti, yaitu:

1. Bagaimana penetapan fungsi budgeter dan fungsi regulasi dalam Peraturan Daerah Provinsi DKI Jakarta Nomor 8 Tahun 2010 tentang Pajak Kendaraan Bermotor?

2. Upaya apa saja yang dilakukan untuk memperbaiki cara pemungutan Pajak Kendaraan Bermotor di DKI Jakarta?

3. Bagaimana pengaruh yang akan terjadi terhadap jumlah kepemilikan kendaraan bermotor pribadi dengan adanya Peraturan Daerah Provinsi DKI Jakarta Nomor 8 Tahun 2010 tentang Pajak Kendaraan Bermotor?

\section{Tujuan Penelitian}

1. untuk mengetahui penetapan fungsi budgeter dan fungsi regulasi dalam Peraturan Daerah Provinsi DKI Jakarta Nomor 8 Tahun 2010 tentang Pajak Kendaraan Bermotor;

2. untuk mengetahui upaya yang dilakukan oleh perangkat daerah di Provinsi DKI Jakarta dalam memperbaiki cara pemungutan Pajak Kendaraan Bermotor; dan 
3. untuk menganalisis pengaruh yang akan terjadi dari adanya penetapan Peraturan Daerah Provinsi DKI Jakarta Nomor 8 Tahun 2010 tentang Pajak Kendaraan Bermotor terhadap jumlah kepemilikan kendaraan bermotor di Jakarta.

\section{Manfaat Penelitian}

Dengan adanya kegiatan penelitian beserta hasil kajiannya, peneliti berharap tulisan-tulisan ini mempunyai manfaat sebagai berikut:

1. Manfaat bagi ilmu pengetahuan, kegiatan penelitian ini akan bermanfaat untuk mengembangkan ilmu di bidang kajian Ilmu Hukum Ekonomi dan Teknologi terutama yang berkaitan dengan Pajak Kendaraan Bermotor, kebijakan makro pengadaan sarana transportasi massal umum, dan kebijakan mikro yang bertujuan membatasi atau mengurangi kepemilikan atau penggunaan kendaraan bermotor oleh masyarakat Jakarta pada khususnya dan oleh masyarakat kota-kota besar di Indonesia pada umumnya; dan

2. Manfaat praktis, kegiatan penelitian ini diharapkan dapat bermanfaat dalam pengkajian Peraturan Daerah Provinsi DKI Jakarta Nomor 8 Tahun 2010 tentang Pajak Kendaraan Bermotor dan kebijakan-kebijakan daerah Provinsi DKI Jakarta lainnya yang berhubungan dengan Pajak Kendaraan Bermotor yang terbaru agar kebijakan-kebijakan tersebut dapat mencerminkan asas keadilan dan kepastian hukum pada masyarakat, dapat mengantisipasi akan terjadinya tax evasion, dan tujuan untuk membatasi atau mengurangi jumlah kepemilikan kendaraan bermotor dapat tercapai dengan baik. 


\section{Tinjauan Pustaka}

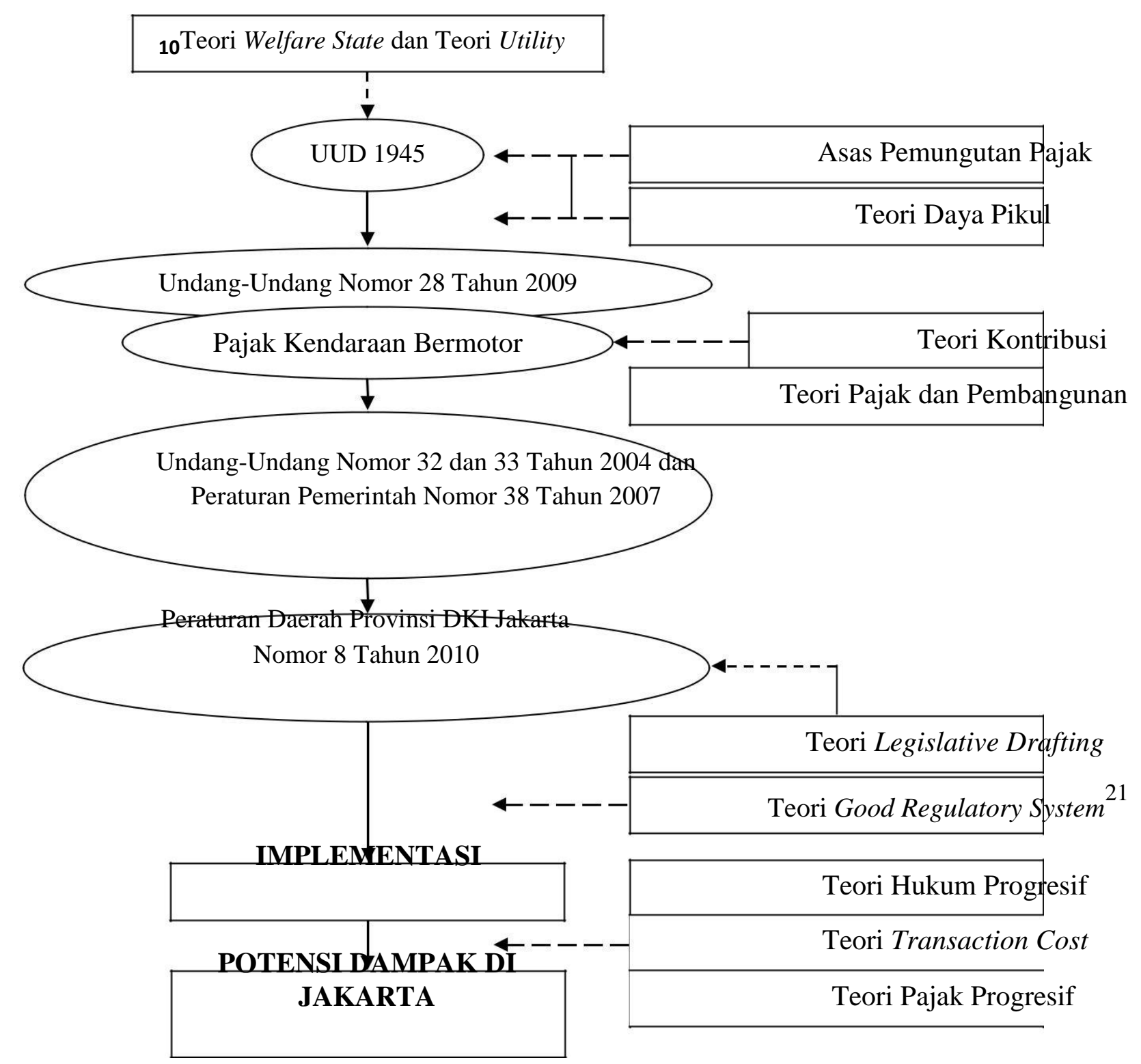

10 Menurut Ogus A. (Ogus A.,2001), "There are two dimensions to a "good" regulatory system. The first relates to the instruments or legal forms selected to achieve the desired outcomes, which will be defined by the objectives. The second relates to the procedures or processes by which the instruments are formulated and applied". 


\section{Metodologi Penelitian}

Penelitian ini merupakan suatu bentuk penelitian campuran untuk meneliti fungsi dan implementasi tarif progresif pada pajak kendaraan bermotor secara empiris di Provinsi Daerah Khusus Ibukota Jakarta. Penelitian ini difokuskan kepada hal-hal mengenai:

1. fungsi tarif progresif pada pajak kendaraan bermotor;

2. implementasi tarif progresif pada pajak kendaraan bermotor dengan objek kendaraan yang dimaksudkan adalah mobil pribadi; dan

3. dampak potensi pergerakan jumlah mobil pribadi terhadap penerapan tarif progresif pada pajak kendaraan bermotor.

Metode pendekatan campuran yang dimaksudkan di sini adalah metode pendekatan yuridis normatif (kualitatif) dan metode pendekatan yuridis empiris (kuantitatif). Yang dimaksudkan dengan pendekatan yuridis normatif adalah pendekatan dari segi peraturan perundang-undangan dan norma-norma hukum sesuai dengan permasalahan yang ada. Pendekatan empiris yang dilakukan akan lebih menekankan kepada penelitian yang bertujuan untuk memperoleh pengetahuan empiris dengan cara terjun langsung ke lapangan. ${ }^{11}$ Dengan menggunakan metode empiris ini, hukum tidak hanya dilihat sebagai law in the book saja, melainkan juga hukum sebagai law in action. ${ }^{12}$ Oleh karena itu, dua metode pendekatan ini dipilih untuk dapat membantu mengkaji penetapan dan pengimplementasian tarif progresif dalam Peraturan Daerah Provinsi DKI Jakarta Nomor 8 Tahun 2010 tentang Pajak Kendaraan Bermotor yang kemudian menimbulkan dampak terhadap kondisi yang akan terjadi di Jakarta.

Penelitian dilakukan di Provinsi Daerah Khusus Ibukota Jakarta beserta kawasan Kepolisian Daerah Metro Jakarta Raya sebagai wilayah hukumnya. Bahan kajian dalam penelitian ini bersumber pada:

\footnotetext{
11 Ronny Hanitijo Soemitro, Metode Penelitian Hukum dan Jurimetri, Jakarta: Ghalia Indonesia, 1990, halaman 40.

12 Satjipto Rahardjo, Hukum Dalam Perspektif Sosial, Bandung: Alumni, 1986, halaman 6.
} 
a. sumber data primer, adalah data peraturan perundang-undangan yang terkait dengan penelitian ini, yaitu Undang-Undang Nomor 28 Tahun 2009 tentang Pajak Daerah dan Retribusi Daerah dan Peraturan Daerah Provinsi DKI Jakarta Nomor 8 Tahun 2010 tentang Pajak Kendaraan Bermotor;

b. sumber data sekunder, adalah sumber data yang memberikan penjelasan tentang sumber data primer, yaitu berupa dokumen, karangan-karangan ilmiah yang saling terkait dengan tema penelitian ini (Pajak Daerah, Pajak Kendaraan Bermotor, dan Pemerintahan Daerah), dan peraturan perundang-undangan pelaksana lainnya yang berkaitan dengan pelaksanaan Pajak Kendaraan Bermotor yang terbaru di Provinsi DKI Jakarta, serta hasil kajian empiris mengenai gambaran yang akan terjadi di masyarakat setelah Perda tentang Pajak Kendaraan Bermotor yang terbaru ini diimplementasikan; dan

c. sumber data tersier yang memberikan penjelasan lebih mendalam mengenai sumber data primer dan sekunder. Sumber data tersier yang digunakan adalah ensiklopedia Indonesia, Kamus Besar Bahasa Inggris versi Cambridge, Black's Law Dictionary, dan Kamus Bahasa InggrisIndonesia.

\section{B. HASIL PENELITIAN DAN PEMBAHASAN}

\section{Fungsi Budgeter dan Regulasi Dalam Peraturan Daerah Provinsi DKI Jakarta Nomor 8 Tahun 2010 Tentang Pajak Kendaraan Bermotor}

\section{a. Fungsi Budgeter}

Pajak kendaraan bermotor termasuk sumber Pendapatan Asli Daerah yang digunakan untuk membiayai kegiatan penyelenggaraan Pemerintahan Daerah. Namun, ada sebagian alokasi khusus yang diwajibkan oleh Undang-Undang Nomor 28 Tahun 2009. Menurut Undang-Undang ini, minimal sebesar 10\% (sepuluh persen) dana yang terkumpul dari hasil pungutan pajak kendaraan bermotor harus 
digunakan untuk pembangunan dan/atau pemeliharaan jalan serta peningkatan moda dan sarana transportasi umum.

Peraturan Daerah Provinsi Daerah Khusus Ibukota Jakarta Nomor 8 Tahun 2010 sebagai salah satu aturan pelaksana dari Undang-Undang Nomor 28 Tahun 2009 pada sektor pajak kendaraan bermotor, mempunyai suatu kebijakan yang berbeda dalam hal alokasi dananya. Menurut Perda DKI Jakarta tentang Pajak Kendaraan Bermotor ini, dana yang terkumpul dari hasil pungutan pajak kendaraan bermotor, minimal sebesar 20\% (dua puluh persen) digunakan untuk pembangunan dan/atau pemeliharaan jalan serta peningkatan moda dan sarana transportasi umum.

Dana yang terkumpul dan dialokasikan khusus untuk sektor transportasi, digunakan oleh Pemerintah Provinsi DKI Jakarta untuk membiayai kebijakan tentang Strategi Pola Transportasi Makro.

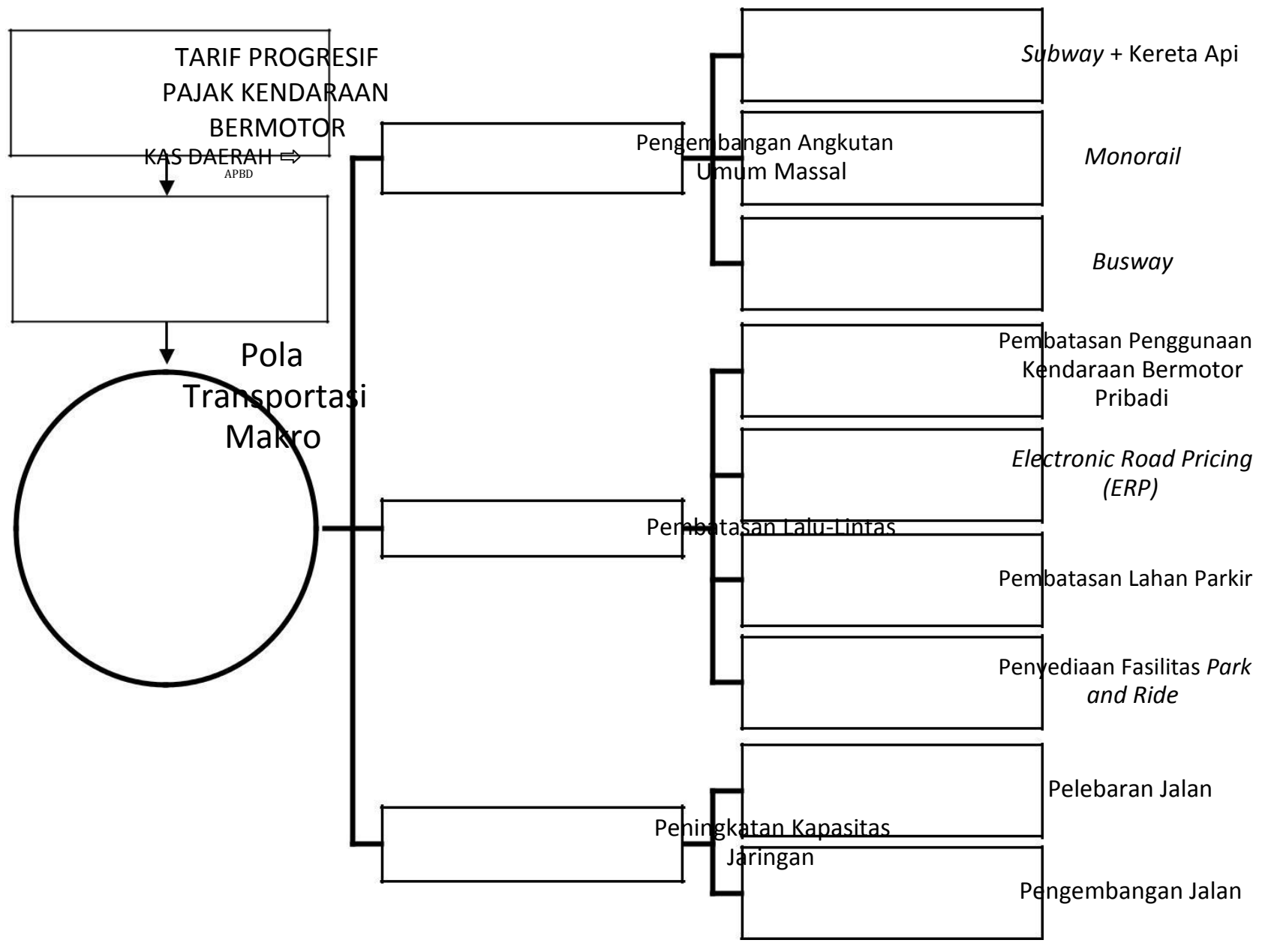




\section{b. Fungsi Regulasi}

Sebagai fungsi regulasi, pungutan Pajak Kendaraan Bermotor berdasarkan Peraturan Daerah Provinsi Daerah Khusus Ibukota Jakarta Nomor 8 Tahun 2010 bertujuan untuk:

1. mengurangi atau membatasi kepemilikan kendaraan bermotor oleh orang pribadi;

2. mendukung kegiatan-kegiatan suatu badan usaha dengan cara membedakan antara kepemilikan kendaraan bermotor oleh orang pribadi dengan kepemilikan kendaraan bermotor oleh badan pribadi (swasta) sehingga kendaraan bermotor atas nama badan tidak terkena tarif progresif;

3. membentuk suatu data base kepemilikan kendaraan bermotor yang baru, valid, dan real; dan

4. memperbaiki sistem pola transportasi makro yang cocok untuk warga Jakarta.

Regulasi dalam pajak kendaraan bermotor ini dilakukan dengan cara menggunakan klasifikasi tarif progresif sebagaimana telah diatur dalam Pasal 7 Peraturan Daerah Provinsi Daerah Khusus Ibukota Jakarta Nomor 8 Tahun 2010.

\section{Upaya Perbaikan Cara Pemungutan Pajak Kendaraan Bermotor di DKI} Jakarta

Pemaksimalan Pendapatan Asli Daerah dari segi Pajak Daerah selalu berhubungan dengan cara pemungutan pajaknya. Pendapatan maksimal akan diraih jika pajak dipungut dengan cara-cara yang efisien sehingga beban biaya pemungutan pajak jauh lebih rendah daripada pendapatan pajak yang dihasilkan. Selain faktor efisiensi pemungutan, faktor ketepatan administrasi dan faktor pelayanan pemungutan pajak kepada masyarakat akan menjadikan masyarakat wajib pajaknya memiliki budaya taat pajak. 
Penerapan tarif progresif dalam Pajak Kendaraan Bermotor sangat membutuhkan adanya ketepatan administrasi dari fiskus dalam pengelolaan data dan fakta wajib pajaknya. Masih ada beberapa data pemilik kendaraan bermotor yang belum berubah walaupun hak kepemilikannya sudah berubah. ${ }^{13}$ Setelah tarif progresif ini secara resmi diterapkan di DKI Jakarta, banyak pemilik kendaraan bermotor di DKI Jakarta mengajukan permohonan balik nama. Ditlantas Polda Metro Jaya dan Dinas Pendapatan Daerah Provinsi DKI Jakarta menjadikan momentum ini sebagai titik awal dari pembenahan administrasi data pemilik kendaraan bermotor di DKI Jakarta.

Setelah melakukan proses-proses perbaikan data mengenai kepemilikan kendaraan bermotor yang berada di wilayah Polda Metro Jaya, langkah peningkatan yang akan dilaksanakan berikutnya adalah peningkatan pelayanan kepada wajib pajak yang akan membayar pajak kendaraan bermotor terutangnya. Pada awalnya, para wajib pajak hanya dapat membayarkan pajak kendaraan bermotor terutangnya di Kantor Samsat tempat dimana kendaraan bermotor tersebut dicatatkan. Seiring dengan padatnya arus lalu-lintas di jalan raya DKI Jakarta dan sangat berartinya waktu yang dimiliki oleh para wajib pajaknya untuk melakukan kegiatan-kegiatan ekonomi, maka para wajib pajak kendaraan bermotor di DKI Jakarta menginginkan adanya suatu proses pembayaran pajak yang cepat, tepat, nyaman, dan dekat dengan kantor atau rumahnya. Selanjutnya, atas masukkan dari warganya tersebut, Dinas Pendapatan Daerah Provinsi DKI Jakarta yang bekerja sama dengan Ditlantas Polda Metro Jaya melakukan peningkatan pelayanan pemungutan pajak di wilayah Jakarta.

Sistem komputerisasi mulai dikembangkan untuk menunjang sistem administrasi dan sistem transaksi pembayaran pajak kendaraan bermotor

13 Hal ini sering terjadi dalam banyak proses jual beli mobil bekas di Indonesia. Seringkali bukti kepemilikan yang sah (BPKB dan STNK) tidak dirubah walaupun sebenarnya hak kepemilikan kendaraan bermotornya sudah berubah seiring telah terjadinya transaksi jual-beli kendaraan bermotor yang dimaksud. 
di DKI Jakarta. Pengembangan pada sistem komputerisasi tersebut mampu mengurangi jumlah waktu yang digunakan untuk melakukan pembayaran pajak kendaraan bermotor di Kantor Samsat. Kisaran waktu yang dibutuhkan (tergantung pada jumlah orang yang mengurus pembayaran pajak tiap harinya) adalah antara 45 (empat puluh lima) menit sampai dengan 2 (dua) jam per orang.

Ditlantas berinisiatif untuk melakukan terobosan dalam pengentasan masalah penumpukan para wajib pajak di Kantor Samsat dengan menerapkan kebijakan praktis untuk mengadakan "Gerai SIM dan STNK". Gerai ini merupakan suatu bus milik Polda Metro Jaya yang digunakan untuk melakukan pelayanan pengurusan perpanjangan SIM dan pembayaran pajak kendaraan bermotor. Bus ini akan berada di suatu tempat strategis di setiap wilayah DKI Jakarta dengan jam operasional antara pukul 08.00 - 13.30. Dengan keberadaan gerai-gerai ini, para wajib pajak lebih memilih menggunakan jasa gerai ini untuk dapat membayarkan pajak kendaraan bermotor terutangnya daripada harus datang ke Kantor Samsat, kecuali jika wajib pajak ingin memperpanjang STNK yang habis masa berlakunya per 5 (lima) tahun. Waktu yang dibutuhkan untuk melakukan proses pembayaran hanya sekitar 15 menit (tergantung jumlah antrian). Hal ini telah sesuai dengan aspirasi masyarakat yang menginginkan waktu yang singkat dalam setiap proses pengurusan pembayaran pajak kendaraan bermotor.

\section{Pengaruh Jumlah Kepemilikan Kendaraan Bermotor Atas Nama Orang} Pribadi Terhadap Implementasi Peraturan Daerah DKI Jakarta Nomor 8 Tahun 2010 Tentang Pajak Kendaraan Bermotor

Penelitian dilakukan secara random terhadap warga Jakarta yang berada dalam masa produktif (bekerja atau pensiun namun masih mempunyai penghasilan tetap) dan memiliki minimal satu buah mobil domisili Jakarta (ditandai dengan plat nomor kode B). Penelitian menggunakan kuesioner yang disebar secara acak untuk menghasilkan 
data nominal. Kuesioner disebar di 5 (lima) wilayah Kota Administrasi Provinsi DKI Jakarta, masing-masing 30 (tiga puluh) berkas kuesioner di Jakarta Utara, Jakarta Barat, Jakarta Pusat, Jakarta Timur, dan Jakarta Selatan. Analisis data dalam penelitian ini akan menghasilkan suatu gambaran tentang dampak yang terjadi sebelum penerapan tarif pajak progresif pada pajak kendaraan bermotor dan dampak yang akan terjadi di masyarakat Jakarta pasca penerapan tarif pajak progresif pada pajak kendaraan bermotor. Walaupun penyebaran kuesioner dilakukan di lima wilayah Kota Administrasi Provinsi DKI Jakarta, namun ternyata terdapat sampel yang berada di luar wilayah Provinsi DKI Jakarta tetapi masih di wilayah hukum Polda Metro Jaya, yaitu Tangerang, dan Bekasi. Responden yang termasuk dalam kategori ini masih dikatakan valid oleh peneliti karena mobilnya masih berkode Jakarta dan mereka masih ber-KTP Provinsi DKI Jakarta. Tabel berikut menampilkan sebaran sampel berdasarkan wilayah domisilinya.

\begin{tabular}{|l|r|r|}
\hline \multicolumn{1}{|c|}{ DOMISILI } & JUMLAH & \multicolumn{1}{c|}{ PERSEN } \\
\hline \hline Jakarta Utara & 20 & $13,3 \%$ \\
\hline Jakarta Barat & 51 & $34,0 \%$ \\
\hline Jakarta Pusat & 16 & $10,7 \%$ \\
\hline Jakarta Timur & 25 & $16,7 \%$ \\
\hline Jakarta Selatan & 19 & $12,7 \%$ \\
\hline Tangerang & 11 & $7,3 \%$ \\
\hline Bekasi & 6 & $4,0 \%$ \\
\hline Tidak Menjawab & 2 & $1,3 \%$ \\
\hline Total & 150 & $100,0 \%$ \\
\hline
\end{tabular}

\begin{tabular}{|l|c|c|c|c|}
\hline \multirow{2}{*}{$\begin{array}{c}\text { Jumlah } \\
\text { Kepemilikan } \\
\begin{array}{c}\text { Mobil Pribadi } \\
\text { Saat Ini }\end{array}\end{array}$} & $\begin{array}{c}\text { Akan } \\
\text { Bertambah }\end{array}$ & $\begin{array}{c}\text { Akan } \\
\text { Tetap }\end{array}$ & $\begin{array}{c}\text { Akan } \\
\text { Berkurang }\end{array}$ & \multirow{2}{*}{ TOTAL } \\
\cline { 2 - 5 } & \multicolumn{4}{|c|}{ Jumlah (\%) } \\
\hline $\begin{array}{l}\text { 1 buah } \\
\text { (Non-Progresif) }\end{array}$ & 25 & 31 & 0 & $\begin{array}{c}56 \\
(38,6)\end{array}$ \\
\hline $\begin{array}{l}>1 \text { buah } \\
\text { (Progresif) }\end{array}$ & 10 & 67 & 12 & $\begin{array}{c}89 \\
(61,4)\end{array}$ \\
\hline Total & 35 & 98 & 12 & $\begin{array}{c}145 \\
(100,0)\end{array}$ \\
\hline
\end{tabular}




\begin{tabular}{|c|c|c|}
\hline & Nilai & Signifikan \\
\hline Pearson Chi-Square $\left(\chi^{L}\right)$ & 25,462 & $<0,05$ \\
\hline
\end{tabular}

Tabel kedua menggambarkan kondisi jumlah kepemilikan mobil pribadi saat ini terhadap potensi pergerakan jumlah kepemilikan mobil pribadi pasca penerapan tarif progresif. Modus dalam tabel ini terletak pada kelompok progresif yang akan tetap mempertahankan jumlah mobilnya di masa yang akan datang, yaitu sebesar 46,2\% (empat puluh enam koma dua persen) dari total sampel. Tabel ini juga menggambarkan dari sisi total bahwa sebesar $24,1 \%$ (dua puluh empat koma satu persen) berpotensi akan menambah jumlah mobil pribadinya, 67,6\% (enam puluh tujuh koma enam persen) berpotensi akan tetap mempertahankan jumlah mobil yang dimilikinya, dan hanya $8,3 \%$ (delapan koma tiga persen) yang berpotensi akan mengurangi jumlah kepemilikan mobil pribadinya. Dari 35 (tiga puluh lima) sampel yang berpotensi menambah jumlah mobil pribadinya, terdapat 25 (dua puluh lima) sampel berasal dari kelompok non-progresif dan 10 (sepuluh) sisanya berasal dari kelompok progresif yang berencana akan menambah jumlah mobil pribadinya.

\begin{tabular}{|c|c|c|c|}
\hline \multirow{3}{*}{$\begin{array}{c}\text { Penghasilan } \\
\text { (per bulan) }\end{array}$} & \multicolumn{2}{|c|}{$\begin{array}{l}\text { Jumlah Kepemilikan Mobil } \\
\text { Dalam Satu Nama/Domisili }\end{array}$} & \multirow[b]{2}{*}{ TOTAL } \\
\hline & 1 buah & $>1$ buah & \\
\hline & \multicolumn{3}{|c|}{ Jumlah (\%) } \\
\hline < Rp. 2.000.000,00 & 0 & 0 & $\begin{array}{c}0 \\
(0,0)\end{array}$ \\
\hline $\begin{array}{l}\text { Rp. } 2.000 .000,00- \\
\text { Rp. } 5.000 .000,00\end{array}$ & 35 & 14 & $\begin{array}{c}49 \\
(36,3)\end{array}$ \\
\hline $\begin{array}{l}\text { Rp. } 5.000 .001,00- \\
\text { Rp. } 10.000 .000,00 \\
\end{array}$ & 19 & 30 & $\begin{array}{c}49 \\
(36,3) \\
\end{array}$ \\
\hline > Rp. 10.000.000,00 & 2 & 35 & $\begin{array}{c}37 \\
(27,4)\end{array}$ \\
\hline Total & 56 & 79 & $\begin{array}{c}135 \\
(100,0)\end{array}$ \\
\hline
\end{tabular}

\begin{tabular}{|l|c|c|}
\hline & Nilai & Signifikan \\
\hline Pearson Chi-Square $\left(\chi^{2}\right)$ & 38,089 & $<0,05$ \\
\hline
\end{tabular}




\begin{tabular}{|l|c|c|c|c|}
\hline \multirow{2}{*}{$\begin{array}{c}\text { Intensitas } \\
\text { Penggunaan Jasa } \\
\text { Angkutan Umum }\end{array}$} & $\begin{array}{c}\text { Akan } \\
\text { Bertambah }\end{array}$ & $\begin{array}{c}\text { Akan } \\
\text { Tetap }\end{array}$ & $\begin{array}{c}\text { Akan } \\
\text { Berkurang }\end{array}$ & \multirow{2}{*}{ TOTAL } \\
\cline { 2 - 5 } & \multicolumn{4}{|c|}{ Jumlah (\%) } \\
\hline $\begin{array}{l}\text { Tidak Pernah } \\
\text { Menggunakan }\end{array}$ & 15 & 55 & 7 & $\begin{array}{c}77 \\
(53,1)\end{array}$ \\
\hline Kadang-Kadang & 16 & 36 & 3 & $\begin{array}{c}55 \\
(37,9)\end{array}$ \\
\hline $\begin{array}{l}\text { Sering } \\
\text { Menggunakan }\end{array}$ & 3 & 3 & 2 & $\begin{array}{c}8 \\
(5,5)\end{array}$ \\
\hline $\begin{array}{l}\text { Selalu } \\
\text { Menggunakan }\end{array}$ & 1 & 4 & 0 & $\begin{array}{c}5 \\
(3,4)\end{array}$ \\
\hline \multicolumn{1}{|c|}{ Total } & 35 & 98 & 12 & $\begin{array}{c}145 \\
(100,0)\end{array}$ \\
\hline
\end{tabular}

\begin{tabular}{|c|c|c|c|c|}
\hline \multirow{3}{*}{$\begin{array}{c}\text { Tingkat } \\
\text { Kepercayaan }\end{array}$} & \multicolumn{3}{|c|}{ Potensi Pergerakan } & \multirow[b]{2}{*}{ TOTAL } \\
\hline & $\begin{array}{c}\text { Akan } \\
\text { Bertambah }\end{array}$ & $\begin{array}{l}\text { Akan } \\
\text { Tetap }\end{array}$ & $\begin{array}{c}\text { Akan } \\
\text { Berkurang }\end{array}$ & \\
\hline & \multicolumn{4}{|c|}{ Jumlah (\%) } \\
\hline Tidak Percaya & 32 & 89 & 3 & $\begin{array}{c}124 \\
(85,5)\end{array}$ \\
\hline Percaya & 3 & 9 & 9 & $\begin{array}{c}21 \\
(14,5)\end{array}$ \\
\hline Total & 35 & 98 & 12 & $\begin{array}{c}145 \\
(100,0)\end{array}$ \\
\hline
\end{tabular}

\begin{tabular}{|c|c|c|}
\hline & Nilai & Signifikan \\
\hline Pearson Chi-Square $\left(\chi^{L}\right)$ & 38,694 & $<0,05$ \\
\hline
\end{tabular}

Potensi pergerakan jumlah kepemilikan mobil pribadi di masa yang akan datang, sangat terpengaruh oleh keadaan status sosial-ekonomi Warga Jakarta, kondisi kualitas dan kuantitas dari sarana/prasarana moda transportasi umum yang tersedia, dan budaya hukum dari para penegak hukum lalu-lintas dan warga di Jakarta yang mempengaruhi tingkat kepercayaan terhadap pencapaian tujuan dari penerapan tarif progresif pada pajak kendaraan bermotor. Dari segi penerapan tarif progresif saat ini, faktor penerapan Peraturan Daerah Provinsi Daerah Khusus Ibukota Jakarta Nomor 8 Tahun 2010 tidak akan membuat Warga Jakarta mengurangi atau membatasi jumlah kepemilikan mobil pribadinya. 


\section{PENUTUP}

\section{Simpulan}

a. Penerapan tarif progresif pada pajak kendaraan bermotor mempunyai fungsi budgeter dan fungsi regulasi dari dan terhadap subjek-objek yang diatur melalui Peraturan Daerah Provinsi DKI Jakarta Nomor 8 Tahun 2010. Fungsi regulasi dari penerapan tarif progresif ini tidak dapat dicapai secara maksimal.

b. Dinas Pendapatan Daerah Provinsi DKI Jakarta bekerja sama dengan Direktorat Lalu-Lintas Polda Metro Jaya, meningkatkan kualitas pelayanannya sehingga semua wajib pajak kendaraan bermotor merasa aman dan nyaman dalam membayar pajak tertanggungnya. Harapannya, dengan adanya peningkatan kualitas ini, pendapatan asli daerah akan semakin meningkat dari sektor pajak kendaraan bermotor. Melalui momentum penerapan tarif progresif pada pajak kendaraan bermotor pribadi ini, Polda Metro Jaya akan mulai untuk melakukan pemutakhiran sistem database kepemilikan kendaraan bermotor pribadi di Jakarta. Upaya pemutakhiran sistem tersebut akan menciptakan asas keadilan dan asas kepastian hukum dalam pemungutan pajak kendaraan bermotor bagi Warga Jakarta yang memiliki kendaraan bermotor pribadi.

c. Penerapan tarif progresif pada pajak kendaraan bermotor tidak mampu untuk mengurangi atau membatasi potensi pertambahan jumlah mobil pribadi di Jakarta. Faktor status sosial-ekonomi dari Warga Jakarta, wawasan terhadap penerapan tarif progresif pada pajak kendaraan bermotor pribadi, dan faktor kondisi jasa angkutan umum yang tidak aman dan nyaman untuk digunakan, lebih kuat mempengaruhi perilaku Warga Jakarta untuk cenderung mempertahankan dan menambah jumlah mobil pribadi yang dimilikinya daripada mengurangi jumlah mobil pribadinya. Oleh karena itu, penerapan tarif progresif pada pajak kendaraan bermotor ini hanya akan meningkatkan Pendapatan Asli Daerah Provinsi DKI 
Jakarta dan tidak akan mampu untuk mengurangi dan/atau membatasi jumlah kepemilikan dan penggunaan kendaraan bermotor pribadi oleh Warga Jakarta.

\section{Saran}

Melalui tulisan ilmiah ini dan berdasarkan data yang telah berhasil maupun yang belum berhasil didapatkan, peneliti ingin melakukan sumbang saran berupa hal-hal sebagai berikut:

a. Jika Pemerintah ingin fokus terhadap pencapaian tujuan dari fungsi regulasinya, Pemerintah harus meningkatkan persentase tarif progresif pada pajak kendaraan bermotor pribadi hingga besaran yang mampu memaksakan Warga Jakarta untuk mengurangi dan/atau membatasi jumlah kepemilikan kendaraan bermotor pribadinya.

b. Untuk mengatasi keterbatasan dalam penyediaan moda transportasi massal umum oleh negara, Pemerintah Provinsi atau Pemerintah Pusat harus bisa menciptakan dan menegakkan suatu kebijakan yang dapat menuntut para pengusaha jasa angkutan umum untuk meningkatkan kualitas dari armada dan pelayanan jasanya. Melalui kebijakan tersebut, Pemerintah harus memaksakan keadaan agar para pengusaha jasa angkutan umum menyediakan armada yang ramah lingkungan dan terawat, jaminan keamanan penumpang dari potensi tindak kriminal di dalam angkutan, dan pengendara yang santun dan berbudaya hukum dalam berkendara. 